( 48 ) 医器学 Vol. 49, No. 6 (1979)

粒径の塵埃がかなり増加することは，同一の手 術室を繰返し使用寸る場合には, 充分の時間の 間隔をおいて使用すべきであることを示してい る. 1 手術室に複数の手術台があり, 複数の出 入口のある手術室は塵埃数が最も多かった。

\section{2. 落下細菌検查}

落下細菌検查は定量的検查ができず, また比 較的大きな粒子に附着した細菌しか捕集できな いなどの久点があるが，手術室の微生物の分布 状態と種類を知るには簡便な方法である. 結果 は浮遊塵埃数の測定結果をよく反映しており, 手術部の老朽化に伴いかなりの程度に污染が進 行していることを示唆していた.

黄色ブドゥ球菌数と 総菌数の比は $17: 167$, グラム陰性桿菌数と総菌数の比は $16: 167$ であ った. 今後手術室増築に当っては以上の点を反 省して手術室の清浄化に努力すると共に, 従来 の手術室も空調設備を更新するなどして, 環境 改善に務めたいと思っている。

\section{4. 岐阜大泭属病院における細菌分布状況と 污染防止法の検討}

岐皁大 中央手術部

○若原和男 赤星義彦

後藤明彦長井松枝

岐阜大 整形外科

松永隆信

岐皁大中央手術部が新築移転し 1 年 10 力月を 経過したが, 我々は手術室内の污染度を知り清 潔環境維持の対策を立てる目的で, 手術室を主 に院内各部所の細菌分布状況を経時的に調査し, さらに bio-clean 手術室を使用して各種污染防 止手段について比較検討した.

（方法）SY 式 pinhole sampler を使用し, 院 内各部所は床上 $75 \mathrm{~cm}$ の空中浮浮遊細菌を, ま た手術室は術創部より $10 \mathrm{~cm}$ 離れた所の細菌数 を測定した。

（成績）1）院内部所における細菌分布：52年 2 月と 53 年 2 月を比較してみると, 大部分の場 所で細菌数の増加傾向がみられるが，一般手術 室は病棟や外来診察室に比べ $1 / 13 \sim 1 / 20$ の清浄度 を示し, 清潔区域としてよく保持されている.

2) 術創附近の浮遊細菌数: 経時的にみると, 一般手術室で一般手術衣を着用して行う手術は
$0.8 / \mathrm{ft}^{3} \sim 2.7 / \mathrm{ft}^{3}$ の間にあり，徐々に污染がす 寸む傾向がみられる. 3) 同定, 薬剤感受性検 查: 術創附近上り捕捉し得た 125 株の分類同定 検查では, Sepidermidis 111 株 $88.8 \%, \mathrm{G}(+)$ Bacillus 5 株 $4.0 \%$, Micrococcus 4 株 $3.2 \%$, Streptococcus 3 株 $2.4 \%$, S. aureus 1 株 0.8 $\%$ ，ブドウ糖非醇酵 $\mathrm{G}(-)$ 掉菌 1 株 $0.8 \%$ であ った。また薬剤感受性検查は50株ずっについて PcA, PcS, CM, TC, CLDM, KM, DKB, CEZ, $\mathrm{EM} の 3$ 濃度デスク法で行ないた. 52 年 2 月の 耐性菌は68\%を，53年 2 月の耐性菌は72\%を占 めてわずかに増加傾向がみられる，4）污染防 止手段の細菌制禦効果: 検査症例は clean orthopedic surgery 35例で, そのうち10例はbioclean 手術室で行なわれたが, bio-clean 手術室 で一般手術衣を用いた場合は一般手術室での $1 / 7$ に, 一般手術衣に頭巾を着用し, 呼気排除装置 を併用した場合は約 $1 / 10 に ， さ ら に$ over $\alpha 11$ 型 ガウに呼気排除装置を併用した場は約 $1 / 30$ と著 明に減少します。これらのことよりbio-clean手 術室で耐水加工 over $\alpha 11$ 型ガウン，呼気排除 装置の使用が極めて重要であると考える。

（まとめ）手術室では細菌数においても耐性菌 の出現率においても污染度が増加寸る傾向がみ られる。 また bio-clean 手術室を使用してもな 扔かつ, 完全な無菌状態をつくり出すことは困 難であり，今後さらに一層清潔な環境保持に留 意する必要がある。

\section{5.手術用縫合系の検討}

弘前大 手術部

大内清太 ○青木紀道 秋田聖霊女子短大

豊問和子

最近の高分子化合物の進歩は縫合材料の面で も寸ぐれた製品を生み，手術の向上に貢献する 一方, 古来よりあった天然縫合材料の絹系や腸 線系製造法にも影響を与之, 隇菌法の進歩と相 まって抗張力も増し, 組織刺激性は減少し, 製 品も均一化されるなどの好結果が得られた. 今 回法物理的性状の類似した NO-3 撚り系, 3-0 編み系絹系拉よび $2-0$ 腸線系の抗張力および切 断伸度が家兔腹壁皮下組織内埋没, 小腸内静置, 胃液内浸漬による経時的すなわち術前值, 術18 